\title{
ANALISIS KINERJA $U$-TURN (STUDI KASUS U-TURN DI ITC JALAN LETJEN SOEPONO, JAKARTA)
}

\author{
oleh : \\ Harwidyo Eko Prasetyo \\ Teknik Sipil Universitas Muhammadiyah Jakarta \\ Email : harwidyo2402@gmail.com \\ Tri Santoso \\ Teknik Sipil Universitas Muhammadiyah Jakarta \\ Email : trisantoso234@gmail.com
}

\begin{abstract}
Abstrak : Jakarta merupakan ibu kota yang mengalami pertambahan penduduk sangat cepat setiap tahunnya, hal tersebut berpengaruh juga pada volume kendaraan yang ada di jalan raya kota Jakarta, salah satunya lalu lintas yang ada di Jalan Letjen Soepono (Arteri Permata Hijau) tepatnya di sebelah barat ITC Permata Hijau. Akses masuk ke ITC Permata Hijau dari arah timur serta penghuni maupun pengunjung Bellezza Apartemen yang akan keluar kearah timur akan bermanuver balik arah pada bukaan median jalan sisi sebelah barat, sehingga akan menimbulkan tundaan dan antrian pada kendaraan yang bergerak searah dengan arah kendaraan sebelum melakukan manuver berbalik arah maupun kendaraan pada jalur yang lain akibat dari manuver kendaraan tersebut. Penelitian ini bertujuan mengetahui seberapa besar pengaruh manuver berbalik arah kendaraan terhadap kinerja jalan, dan menentukan tundaan operasional dari arus lalu lintas pada kedua arah, serta mengevaluasi karakteristik lalu lintas akibat $U$-Turn. Metode untuk acuan utama yaitu dengan menggunakan metode Manual Kapasitas Jalan Indonesia (MKJI) tahun 1997. Hasil penelitian bahwa volume terbesar di ruas jalan Letjen Soepono (Arteri Permata Hijau) terjadi pada hari kerja 1 pukul 07.00 - 08.00 arah Kebon Jeruk - Simprug sebesar $4908.65 \mathrm{smp} / \mathrm{jam}$ dengan tingkat pelayanan jalan $(\mathrm{Q} / \mathrm{C})>0,75$. Kecepatan kendaraan terendah pada arus terganggu oleh U-Turn adalah 38,01 km/jam terjadi pada arah Kebon Jeruk - Simprug, hari kerja 2 antara pukul 07.00 - 08.00 . Rata-rata jumlah kendaraan dalam satu kasus U-Turn antara 3.13 - 3.47 kendaraan sedangkan rata-rata tundaan per kendaraan yang dipengaruhi adalah antara 6.77 - 7.73 detik. Analisa Greenshield \& Shockwave didapat panjang antrian antara 90 - 350 meter.
\end{abstract}

Kata kunci: U-Turn, Greenshield, Shockwave, Manual Kapasitas Jalan Indonesia (MKJI) tahun 1997

Abstract : Jakarta is a capital city which experiences a very rapid population growth every year, this also affects the volume of vehicles on the Jakarta city highway, one of which is the traffic on Jalan Letjen Soepono (Permata Hijau Artery) precisely to the west of ITC Permata Hijau. Access to the Permata Hijau ITC from the east as well as residents and visitors of Bellezza Apartment that will exit eastward will maneuver in the direction of the median opening on the west side of the road, which will cause delays and queues on vehicles that move in the direction of the vehicle before maneuvering turns direction and vehicle on the other lane due to the maneuver of the vehicle. This study aims to determine how much influence the vehicle's turnaround maneuver on road performance, and determine the operational delay of traffic flow in both directions, and evaluate the characteristics of traffic due to U-Turn. The method for the main reference is to use the Indonesian Road Capacity Manual (MKJI) method in 1997. The results of the study showed that the largest volume in the Letjen Soepono (Arteri Permata Hijau) section occurred on working day 1 at $07.00-08.00$ Kebon Jeruk - Simprug direction at $4908.65 \mathrm{smp} /$ hour with the level of road service $(Q / C)>0.75$. The lowest vehicle speed on the current interrupted by U-Turn is $38.01 \mathrm{~km} / \mathrm{h}$ in the direction of Kebon Jeruk - Simprug, weekday 2 between 07.00 - 08.00. The average number of vehicles in a U-turn case is between $3.13-3.47$ 
vehicles while the average delay per vehicle affected is between 6.77 - 7.73 seconds. Greenshield \& Shockwave analysis obtained queue length between 90-350 meters.

Keywords : U-Turn, Greenshield, Shockwave, Indonesian Road Capacity Manual (MKJI) in 1997

\section{Pendahuluan}

ITC Permata Hijau adalah sebuah Trade Center yang berlokasi di jalan Letjen Soepono. Berbeda dari ITC lainnya, International Trade Center di Permata Hijau ini sejak awal menggunakan kata 'Grand' di depannya yang mana dimaksudkan untuk menegaskan 'kelas' yang ingin disasar. Mall enam lantai yang berada di atas khalayak kelas menengah bawah yang biasa jadi pengunjung mall berlabel 'ITC' lainnya.

Pusat perbelanjaan milik PT Duta Pertiwi Tbk (Sinarmas Group) ini juga memiliki dua tower apartemen di bagian belakang dengan nama Grand Permata, apartemen ini dibangun setinggi 17 lantai. Diseberang jalan terdapat apartemen The Bellezza yang bergaya arsitektur Roma, The Belezza di Permata Hijau, Jakarta Barat merupakan kawasan 5 in 1: apartemen, service residences (hotel), perkantoran, pusat perbelanjaan, dan perkantoran. Bangunannya sendiri terdiri dari empat tower dengan ketinggian 24 lantai. Milik PT Sumber Daya Nusaphala, anak perusahaan Gapura Prima Group, pembangunan kompleks ini ditangani oleh PT Pembangunan Perumahan (persero).

Data jumlah penduduk di kota Jakarta selatan kurang lebih 1,89 juta jiwa, semakin bertambahnya jumlah penduduk kota Jakarta tiap tahun maka berpengaruh juga pada volume kendaraan yang melintas di jalan raya kota Jakarta. Pengaruh ini bertambah pada Jalan Letnan Soepono (Arteri Permata Hijau) tepatnya di sebelah barat ITC Permata Hijau karena dipengaruhi oleh kedua Apartemen yang berseberangan.
Akses masuk ke ITC Permata Hijau dari arah timur serta Penghuni maupun pengunjung Bellezza Apartemen yang akan keluar kearah timur akan bermanuver balik arah pada bukaan median jalan sisi sebelah barat, sehingga akan menimbulkan tundaan dan antrian pada kendaraan yang bergerak searah dengan arah kendaraan sebelum melakukan manuver berbalik arah maupun kendaraan pada jalur yang lain akibat dari manuver kendaraan tersebut.

Jalan Letnan Jenderal Soepono tepatnya di depan ITC Permata Hijau adalah jalan dengan 6 lajur dan 2 arah, lebar jalan 10,5 meter untuk satu arah, lebar median 1,15 meter dan terdapat 2 putaran balik di sebelah barat sebelum persimpangan jalan serta disebelah timur sebelum persimpangan jalan. Difungsikannya 2 lajur pada arah yang satu dan arah yang lain sebagai jalur khusus busway sehingga menyebabkan jalur yang dipakai untuk kendaraan umum hanya sebanyak 4 lajur. Hal ini berpengaruh terhadap tingkat kepadatan pada jalan tersebut karena menurut saya perencanaan awal jalan tersebut adalah 6 lajur 2 arah, lebar jalan 10,50 meter (arah kebon jeruk - simprug), lebar jalan 10,50 meter (arah simprug kebon jeruk).

Maksud dan Tujuan dari kajian ini adalah didapatkan hasil rekomendasi awal kondisi lalu lintas di U-Turn di Jalan LetnanJenderal Soepono tepatnya di depan ITC Permata Hijau.

Di Jakarta fasilitas U-Turn dapat ditemukan pada jalan-jalan utama dengan median, tetapi median tersebut sangat sempit dan dibuat secara fisik untuk memisahkan arah 
lalu lintas yang berlawanan pada jalan padat dan pada jalan dengan kecepatan tinggi. $U$ Turn didekat persimpangan juga digunakan di Jakarta pada kondisi volume lalu lintas yang padat, dimana satu atau lebih konflik arus langsung diarahkan melalui U-Turn tersebut untuk mengurangi jumlah konflik diantara persimpangan dan dengan demikian tercapai kondisi pengoperasian lebih baik. Tetapi fasilitas U-Turn tidak secara keseluruhan mengatasi masalah konflik, sebab U-Turn itu sendiri akan menimbulkan permasalahan konflik tersendiri dalam bentuk hambatan terhadap arus lalu lintas searah dan juga arus yang berlawanan arah. Berikut dapat dijelaskan beberapa butir pengaruh dari fasilitas $U$ Turn:

1. Dalam melakukan U-Turn, kendaraan akan melakukan pendekatan yang secara normal dari lajur cepat, dan melambat atau berhenti, perlambatan ini akan mengganggu arus lalu lintas pada arah yang sama.

2. Pada umumnya kendaraan tidak dapat melakukan $U$-Turn secara langsung dan akan menunggu gap yang memungkinkan di dalam arus lalu lintas yang berlawanan arah. Dengan median yang sempit kendaraan yang melakukan U-Turn akan menyebabkan kendaraan yang lain dalam arus yang sama berhenti dan akan membentuk antrean pada lajur cepat. Antrian ini menimbulkan bottleneck yang dapat dikatakan sebagai hambatan samping terhadap lalu lintas di jalur lain pada arah yang sama.

3. Kendaraan yang melakukan U-Turn dipengaruhi oleh ukuran fasilitas U-Turn, karakteristik kendaraan dan kemampuan pengemudi. Median yang sempit atau bukaan median yang sempit memaksa pengemudi melakukan U-Turn menghambat lebih dari dua lajur dalam dari jalan 2 arah dengan melakukan $U$ Turn dari lajur luar atau melakukan $U$ Turn masuk ke lajur luar.

4. Fasilitas $U$-Turn sering ditemukan pada daerah sibuk dengan kondisi lalu lintas mendekati kapasitas. Dalam kondisi ini lalu lintas yang terhambat disebabkan $U$ Turn relative mempunyai dampak yang lebih besar dalam bentuk tundaan.

Lingkungan perkotaan yang memiliki jalan 2 arah dipisahkan oleh median yang lebih tinggi dari permukaan jalan, diperlukan adanya perlakuan khusus untuk lalu lintas melakukan U-Turn. U-Turn diizinkan pada setiap bukaan median, kecuali ada larangan dengan tanda lalu lintas. Dari penelitian sebelumnya terbukti bahwa, dimanapun dimungkinkan suatu desain jalan baru dengan pemisah memiliki lebar median yang dapat mencukupi untuk gerakan membelok ke kanan yang normal dan gerakan $U$-Turn dengan menggunakan lajur tunggu pada median yang akan melindungi dan menampung volume jam kendaraan yang membelok secara normal, U-Turn tidak diizinkan dari lajur menerus. Bagaimanapun juga median yang mempunyai lebar mencukupi untuk melindungi kendaraan yang berdiri didalam bukaan median dapat diizinkan. Manajemen lalu lintas di Eropa dan Amerika telah menghindari penggunaan fasilitas $U$-Turn pada jalan kota. Oleh karena itu, sangat sedikit penelitian terdahulu yang berkaitan dengan tujuan dari studi ini. Bilamana ada beberapa penelitian, penguraian biasanya hanya berupa garis besarnya saja. Bina marga telah menerbitkan dua standar yang berhubungan dengan U-Turn, yaitu :

1. Tata cara perencanaan pemisah, No.014/T/BNTK/1990;

2. Spesifikasi bukaan pemisah jalur, SK SNI 2444:2008. 


\section{Radius Putar}

Radius berputar minimum kendaraan adalah jari-jari jejak yang dibuat oleh roda atau ban depan bagian luar apabila kendaraan membuat perputaran yang paling tajam yang mungkin dilakukan pada kecepatan kurang dari $15 \mathrm{~km} / \mathrm{jam}$. Besaran radius putar disajikan dengan dimensi kendaraan rencana seperti disajikan pada tabel 1.

Tabel 1. Dimensi Kendaraan Rencana

\section{Perkotaan}

\begin{tabular}{|c|c|c|c|c|c|c|c|c|}
\hline \multirow{2}{*}{$\begin{array}{c}\text { Kendaraan } \\
\text { Rencana }\end{array}$} & \multirow{2}{*}{ Simbol } & \multicolumn{3}{|c|}{ Dimensi Kendaraan (m) } & \multicolumn{2}{|c|}{$\begin{array}{c}\text { Dimensi Tonjolan } \\
(\mathbf{m})\end{array}$} & $\begin{array}{c}\text { Radius } \\
\text { Putar } \\
\text { Minimum } \\
\text { (m) }\end{array}$ & $\begin{array}{c}\text { Radius } \\
\text { Tonjolan } \\
\text { Minimum } \\
\text { (m) }\end{array}$ \\
\cline { 3 - 8 } & & Tinggi & Lebar & Panjang & Depan & Belakang & & \\
\hline Truk As Tunggal & SU & 4,1 & 2,4 & 9,0 & 1,1 & 1,7 & 12,8 & 8,6 \\
City Transit Bus & CB & 3,2 & 2,5 & 12,0 & 2,0 & 2,3 & 12,8 & 7,5 \\
Bis Gandeng & A-BUS & 3,4 & 2,5 & 18,0 & 2,5 & 2,9 & 12,1 & 6,5 \\
\hline
\end{tabular}

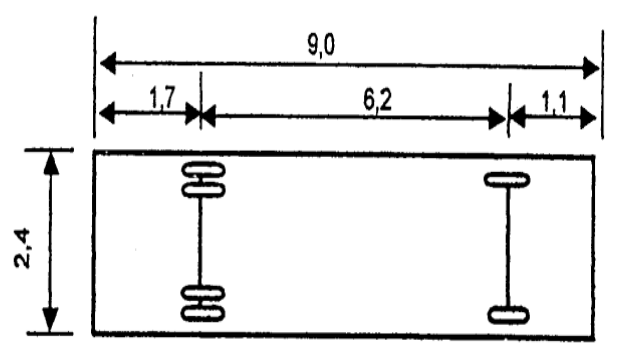

Gambar 1. Kendaraan Truk As Tunggal

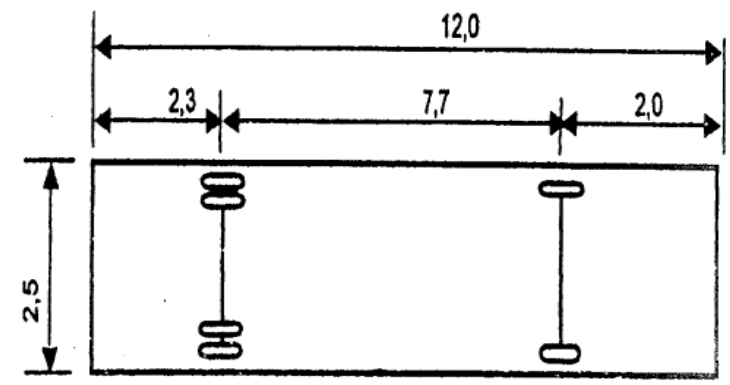

Gambar 2. Kendaraan City Transit Bus

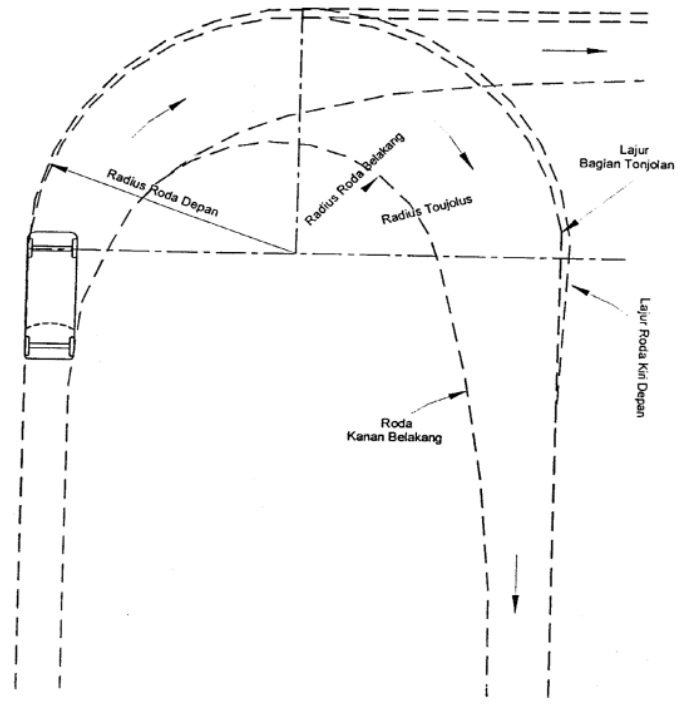

Gambar 3. Jari-jari putaran kendaraan. Sumber : Pedoman Perencanaan Putaran Balik/U-Turn (Bina Marga)

\section{Kebutuhan Lebar Median Ideal Berdasarkan Radius Putar}

Lebar median ideal berdasarkan radius putar kendaraan rencana yang digunakan pada perencanaan putaran balik disajikan pada tabel dibawah. Lebar median ideal adalah lebar median yang diperlukan oleh kendaraan dalam melakukan gerakan putaran balik dari lajur yang paling dalam ke lajur yang paling dalam pada lajur lawan. Apabila tidak tersedia lahan yang cukup untuk menyediakan lebar median ideal dan dimungkinkan untuk melakukan gerakan putaran balik dari lajur yang paling dalam ke lajur kedua atau ketiga (jalan 6/2 D) atau ahu jalan (jalan 4/2 D), direkomendasikan kebutuhan median seperti disajikan pada tabel dibawah. 
Tabel 2. Lebar Median Ideal

\begin{tabular}{|c|c|c|c|c|}
\hline \multirow{4}{*}{ Jenis Putaran } & \multirow{4}{*}{$\begin{array}{c}\text { Lebar } \\
\text { Lajur (m) }\end{array}$} & $\begin{array}{l}\text { Kend } \\
\text { Kecil }\end{array}$ & $\begin{array}{c}\text { Kend } \\
\text { Sedang }\end{array}$ & $\begin{array}{l}\text { Kend } \\
\text { Besar }\end{array}$ \\
\hline & & \multicolumn{3}{|c|}{ Panjang Kendaraan Rencana } \\
\hline & & $5,8 \mathrm{~m}$ & $12,1 \mathrm{~m}$ & $21 \mathrm{~m}$ \\
\hline & & \multicolumn{3}{|c|}{ Lebar Median Ideal (m) } \\
\hline$\because----------1$ & 3,5 & 8,0 & 18,5 & 20,0 \\
\hline & 3 & 8,5 & 19,0 & 21,0 \\
\hline :ニニニーニ & 2,75 & 9,0 & 19,5 & 21,5 \\
\hline
\end{tabular}

Tabel 3. Kebutuhan lebar median apabila gerakan putaran balik dari lajur dalam ke lajur kedua jalur lawan

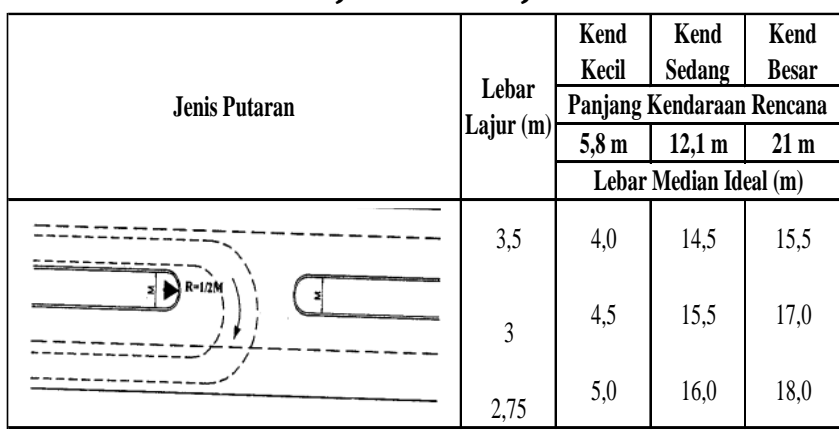

Tabel 4. Kebutuhan lebar median ideal apabila gerakan putaran balik dari lajur dalam ke bahu jalan (4/2 D) atau lajur ketiga (6/2 D) jalur lawan

\begin{tabular}{|c|c|c|c|c|}
\hline \multirow{4}{*}{ Jenis Putaran } & \multirow{4}{*}{$\begin{array}{c}\text { Lebar } \\
\text { Lajur (m) }\end{array}$} & $\begin{array}{l}\text { Kend } \\
\text { Kecil }\end{array}$ & $\begin{array}{c}\text { Kend } \\
\text { Sedang }\end{array}$ & $\begin{array}{l}\text { Kend } \\
\text { Besar }\end{array}$ \\
\hline & & \multicolumn{3}{|c|}{ Panjang Kendaraan Rencana } \\
\hline & & $5,8 \mathrm{~m}$ & $12,1 \mathrm{~m}$ & $21 \mathrm{~m}$ \\
\hline & & \multicolumn{3}{|c|}{ Lebar Median Ideal (m) } \\
\hline ニニニニニニニニーーーーーーーーーーーーー & 3,5 & 0,5 & 11,0 & 12,0 \\
\hline$---------\left.\frac{1}{1}\right|_{1} ^{1}+1$ & 3 & 1,5 & 12,5 & 14,0 \\
\hline 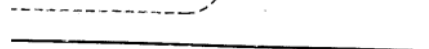 & & 2,0 & 13,0 & 15,0 \\
\hline
\end{tabular}

Berdasarkan Manual Kapasitas Jalan Indonesia (MKJI) 1997, Direktorat Jenderal Bina Marga Direktorat Bina Jalan Kota, Volume lalu-lintas ruas jalan adalah jumlah atau banyaknya kendaraan yang melewati suatu titik tertentu pada ruas jalan dalam suatu satuan waktu tertentu. Volume lalulintas dua arah pada jam paling sibuk dalam sehari dipakai sebagai dasar untuk analisa unjuk kerja ruas jalan dan persimpangan yang ada. Untuk kepentingan analisis, kendaraan yang disurvei diklasifikasikan atas :

1. Kendaraan Ringan (Light Vehicle/LV) yang terdiri dari Jeep, Station Wagon, Colt, Sedan, Bis mini, Combi, Pick Up, Dll;

2. Kendaraan berat (Heavy Vehicle/HV), terdiri dari Bus dan Truk;

3. Sepeda motor (Motorcycle/MC);

Data hasil survei per-jenis kendaraan tersebut selanjutnya dikonversikan dalam Satuan Mobil Penumpang (SMP) guna menyamakan tingkat penggunaan ruang keseluruhan jenis kendaraan. Untuk keperluan ini, MKJI (1997) telah merekomendasikan nilai konversi untuk masing-masing klasifikasi kendaraan sebagaimana dapat dilihat pada Tabel dibawah ini.

Tabel 5. Nilai Ekivalen Mobil Penumpang

\begin{tabular}{|c|c|c|c|c|}
\hline \multicolumn{5}{|c|}{ Nilai Ekivalen Mobil Penumpang (EMP) } \\
\hline \multirow{2}{*}{$\begin{array}{c}\text { Tipe } \\
\text { Jalan }\end{array}$} & \multirow{2}{*}{$\begin{array}{c}\text { Lebar } \\
\text { Jalur (m) }\end{array}$} & \multirow{2}{*}{$\begin{array}{l}\text { Tot Arus } \\
\text { (Km/Jam) }\end{array}$} & \multicolumn{2}{|c|}{ Faktor EMP } \\
\hline & & & HV & MC \\
\hline $4 / 2$ UD & & $>3.700$ & 1,3 & 0,40 \\
\hline $4 / 2$ UD & & $\geq 3.700$ & 1,2 & 0,25 \\
\hline \multirow{2}{*}{$2 / 2 \mathrm{UD}$} & \multirow{2}{*}{$>6$} & $>1.800$ & 1,3 & 0,40 \\
\hline & & $\geq 1.800$ & 1,2 & 0,25 \\
\hline \multirow{2}{*}{ 2/2 UD } & \multirow{2}{*}{$\leq 6$} & $>1.800$ & 1,3 & 0,5 \\
\hline & & $\geq 1.800$ & 1,2 & 0,35 \\
\hline
\end{tabular}

Sumber : Manual Kapasitas Jalan Indonesia, 1997

Tabel 6. Faktor EMP untuk tipe pendekat

\begin{tabular}{|l|c|c|}
\hline \multirow{2}{*}{ Jenis Kendaraan } & \multicolumn{2}{|c|}{$\begin{array}{c}\text { Faktor EMP Untuk Tipe } \\
\text { Pendekat }\end{array}$} \\
\cline { 2 - 3 } & Terlindung & Terlawan \\
\hline $\begin{array}{l}\text { Kendaraan Ringan } \\
\text { (LV) }\end{array}$ & 1,0 & 1,0 \\
\hline $\begin{array}{l}\text { Kendaraan Berat } \\
\text { (HV) }\end{array}$ & 1,3 & 1,3 \\
\hline Sepeda Motor (MC) & 0,2 & 0,4 \\
\hline
\end{tabular}

Sumber : Manual Kapasitas Jalan Indonesia, 1997

Kapasitas jalan perkotaan dihitung dari kapasitas dasar. Kapasitas dasar adalah 
jumlah kendaraan maksimum yang dapat melintasi suatu penampang pada suatu jalur atau jalan selama 1 (satu) jam, Dalam keadaan jalan dan lalu-lintas yang mendekati ideal dapat dicapai. Besarnya kapasitas jalan dapat dijabarkan sebagai berikut :

\section{C $=\operatorname{Co} \times$ FCw $\times$ FCsp $\times$ FCsf $\times$ FCcs}

dimana :

$\mathrm{C}=$ kapasitas ruas jalan (SMP/Jam)

Co $=$ kapasitas dasar

$\mathrm{FCw}$ = faktor penyesuaian kapasitas untuk lebar jalur lalu-lintas

FCsp = faktor penyesuaian kapasitas untuk pemisahan arah

FCsf = faktor penyesuaian kapasitas untuk hambatan samping

FCcs $=$ faktor penyesuaian kapasitas untuk ukuran kota.

1. Kapasitas Dasar

Besarnya kapasitas dasar jalan kota yang dijadikan acuan adalah sebagai Berikut :

Tabel 6. Kapasitas Dasar

\begin{tabular}{|l|c|l|}
\hline \multicolumn{1}{|c|}{ Tipe Jalan } & $\begin{array}{c}\text { Kapasitas } \\
\text { Dasar } \\
\text { (SMP/Jam) }\end{array}$ & Keterangan \\
\hline $\begin{array}{l}\text { 4 Jalur dipisah } \\
\text { atau jalan satu } \\
\text { arah }\end{array}$ & 1.650 & Tiap Lajur \\
\hline $\begin{array}{l}\text { 4 Lajur tidak } \\
\text { dipisah }\end{array}$ & 1.500 & Tiap Lajur \\
\hline $\begin{array}{l}\text { 2 lajur tidak } \\
\text { dipisah }\end{array}$ & 2.900 & Kedua Lajur \\
\hline
\end{tabular}

Sumber : Manual Kapasitas Jalan Indonesia, 1997

2. Faktor penyesuaian lebar jalur (FCw) Faktor penyesuaian lebar jalan seperti ditunjukkan pada tabel berikut:
Tabel 7. Faktor Penyesuaian lebar jalur

\section{(FCw)}

\begin{tabular}{|l|c|c|c|}
\hline \multicolumn{1}{|c|}{ Tipe Jalan } & $\begin{array}{c}\text { Lebar } \\
\text { Jalan } \\
\text { Efektif }\end{array}$ & $\mathbf{C w}$ & Keterangan \\
\hline 4 Jalur dipisah & 3,00 & 0,92 & \\
atau jalan satu & 3,25 & 0,96 & Tiap Lajur \\
arah & 3,50 & 1,00 & \\
& 3,75 & 1,04 & \\
& 4,00 & 1,08 & \\
4 Lajur tidak & 3,00 & 0,91 & \\
dipisah & 3,25 & 0,95 & \\
& 3,50 & 1,00 & Tiap Lajur \\
& 3,75 & 1,05 & \\
& 4,00 & 1,09 & \\
2 lajur tidak & 5,00 & 0,56 & \\
dipisah & 6,00 & 0,87 & \\
& 7,00 & 1,00 & \multirow{2}{*}{ Kedua Arah } \\
& 8,00 & 1,14 & \\
& 9,00 & 1,25 & \\
\hline
\end{tabular}

Sumber : Manual Kapasitas Jalan Indonesia, 1997

3. Faktor penyesuaian arah lalu-lintas (FCsp)

Besarnya faktor penyesuaian pada jalan tanpa menggunakan pemisah tergantung kepada besarnya split kedua arah seperti tabel berikut :

Tabel 8. Faktor penyesuaian arah lalulintas (FCsp)

\begin{tabular}{|c|c|c|c|c|c|c|}
\hline \multicolumn{2}{|c|}{$\begin{array}{c}\text { Split Arah \% } \\
\text { - \% }\end{array}$} & $\begin{array}{c}50- \\
50\end{array}$ & $\begin{array}{c}55- \\
45\end{array}$ & $\begin{array}{c}60- \\
40\end{array}$ & $\begin{array}{c}65- \\
35\end{array}$ & $\begin{array}{c}70- \\
30\end{array}$ \\
\hline \multirow[b]{2}{*}{ Fsp } & $2 / 2$ & 1,00 & 0,97 & 0,94 & 0,91 & 0,88 \\
\hline & $\begin{array}{l}/ 2 \\
\text { Tidak } \\
\text { Dipisah }\end{array}$ & 1,00 & 0,985 & 0,97 & 0,955 & 0,94 \\
\hline
\end{tabular}

Sumber : Manual Kapasitas Jalan Indonesia, 1997

4. Faktor penyesuaian kerb dan bahu jalan (FCsf)

Faktor penyesuaian kapasitas jalan antar kota terhadap lebar jalan dihitung dengan menggunakan tabel berikut : 
Tabel 9. Faktor penyesuaian kerb dan bahu jalan (FCsf)

\begin{tabular}{|c|c|c|c|c|c|}
\hline \multirow[t]{3}{*}{$\begin{array}{c}\text { Tipe } \\
\text { Jalan }\end{array}$} & \multirow{3}{*}{$\begin{array}{c}\text { Kelas } \\
\text { Hambatan } \\
\text { Samping }\end{array}$} & \multirow{2}{*}{\multicolumn{4}{|c|}{$\begin{array}{c}\text { Faktor Penyesuaian Untuk } \\
\text { Hambatan Samping dan } \\
\text { Lebar Bahu }\end{array}$}} \\
\hline & & & & & \\
\hline & & $\leq 0,5$ & 1,0 & 1,5 & $\geq 2,0$ \\
\hline \multirow{5}{*}{$4 / 2 \mathrm{D}$} & VL & 0,96 & 0,98 & 1,01 & 1,03 \\
\hline & $\mathrm{L}$ & 0,94 & 0,97 & 1,00 & 1,02 \\
\hline & M & 0,92 & 0,95 & 0,98 & 1,00 \\
\hline & $\mathrm{H}$ & 0,88 & 0,92 & 0,95 & 0,98 \\
\hline & VH & 0,84 & 0,88 & 0,92 & 0,96 \\
\hline \multirow{5}{*}{$\begin{array}{l}4 / 2 \\
\text { UD }\end{array}$} & VL & 0,96 & 0,99 & 1,01 & 1,03 \\
\hline & $\mathrm{L}$ & 0,94 & 0,97 & 1,00 & 1,02 \\
\hline & M & 0,92 & 0,95 & 0,98 & 1,00 \\
\hline & $\mathrm{H}$ & 0,87 & 0,91 & 0,94 & 0,98 \\
\hline & $\mathrm{VH}$ & 0,80 & 0,86 & 0,90 & 0,96 \\
\hline $2 / 2$ & VL & 0,94 & 0,96 & 0,99 & 1,01 \\
\hline UD & $\mathrm{L}$ & 0,92 & 0,94 & 0,97 & 1,00 \\
\hline atau & M & 0,89 & 0,92 & 0,95 & 0,98 \\
\hline Jalan & $\mathrm{H}$ & 0,82 & 0,86 & 0,90 & 0,95 \\
\hline Satu & VH & 0,73 & 0,79 & 0,85 & 0,91 \\
\hline Arah & & & & & \\
\hline
\end{tabular}

Sumber : Manual Kapasitas Jalan Indonesia, 1997

\section{Catatan :}

- Tabel tersebut di atas menganggap bahwa lebar bahu di kiri dan kanan jalan sama, bila lebar bahu kiri dan kanan berbeda maka digunakan nilai rataratanya.

- Lebar efektif bahu adalah lebar yang bebas dari segala rintangan, bila di tengah terdapat pohon, maka lebar efektifnya adalah setengahnya.

\section{Faktor Ukuran Kota ( Fcs )}

Berdasarkan hasil penelitian ternyata ukuran kota mempengaruhi kapasitas seperti ditunjukkan dalam tabel berikut :

Tabel 10. Faktor Ukuran Kota (Fcs)

\begin{tabular}{|c|c|}
\hline $\begin{array}{c}\text { Ukuran Kota } \\
\text { (Juta Orang) }\end{array}$ & $\begin{array}{c}\text { Factor Ukuran Kota } \\
\text { (Fcs) }\end{array}$ \\
\hline$<0,1$ & 0,86 \\
\hline $0,1-0,5$ & 0,90 \\
\hline $0,5-1,0$ & 0,94 \\
\hline $1,0-3,0$ & 1,00 \\
\hline
\end{tabular}

\begin{tabular}{|c|c|}
\hline $\begin{array}{c}\text { Ukuran Kota } \\
\text { (Juta Orang) }\end{array}$ & $\begin{array}{c}\text { Factor Ukuran Kota } \\
\text { (Fcs) }\end{array}$ \\
\hline$\leq 3,0$ & 1,01 \\
\hline
\end{tabular}

Sumber : Manual Kapasitas Jalan Indonesia, 1997

\section{Ekivalen mobil Penumpang}

Tabel 11. Ekivalen Mobil Penumpang

\begin{tabular}{|c|c|c|c|c|}
\hline \multirow{5}{*}{$\begin{array}{c}\text { Tipe Jalan : } \\
\text { Jalan Tak Terbagi }\end{array}$} & \multirow{5}{*}{$\begin{array}{c}\text { Arus lalu } \\
\text { lintas Total } \\
\text { dua Arah } \\
\text { (Kend/ jam) }\end{array}$} & \multicolumn{3}{|c|}{ emp } \\
\hline & & \multirow{4}{*}{ HV } & \multicolumn{2}{|c|}{$\mathrm{MC}$} \\
\hline & & & \multirow{2}{*}{\multicolumn{2}{|c|}{$\begin{array}{l}\text { Lebar Jalur } \\
\text { Lalu Lintas }\end{array}$}} \\
\hline & & & & \\
\hline & & & $<6$ & $>6$ \\
\hline \multirow{2}{*}{$\begin{array}{l}\text { Dua Lajur tak } \\
\text { terbagi }(2 / 2 \text { UD) }\end{array}$} & 0 & 1,3 & 0,5 & 0,4 \\
\hline & $>1.800$ & 1,2 & 0,35 & 0,25 \\
\hline \multirow{2}{*}{$\begin{array}{l}\text { Empat lajur tak } \\
\text { terbagi ( } 4 / 2 \text { UD) }\end{array}$} & 0 & 1,3 & \multicolumn{2}{|c|}{0,4} \\
\hline & $>3.700$ & 1,2 & \multicolumn{2}{|c|}{0,25} \\
\hline
\end{tabular}

Sumber : Manual Kapasitas Jalan Indonesia, 1997

\section{Metode}

Tujuan metodologi penelitian ini adalah mendeskripsikan kualitatif dan kuantitatif (MKJI) 1997 guna mendapatkan hasil yang di harapkan. Prinsip dasar dari pengukuran adalah mencatat waktu tempuh dengan survei input output, survei mencatat waktu kedatangan dan waktu keberangkatan dari setiap kendaraan yang melalui lokasi yang di uji, dan menghitung waktu tempuh dengan mengurangkan waktu keberangkatan dan waktu kedatangan.

Dalam penelitian ini ada 2 daerah studi :

a. Daerah studi di batasi dengan panjang kira-kira $50 \mathrm{~m}$ masing-masing sisi dari fasilitas Putaran balik yang memberikan total panjang lokasi $100 \mathrm{~m}$. Pada area ini untuk pengumpulan data dimana arus lalu lintas dinyatakan sebagai arus terganggu oleh satu kendaraan rencana yang melakukan Putaran balik.

b. Daerah studi di batasi dengan panjang kira-kira $100 \mathrm{~m}$ yang jauh dari fasilitas Putaran balik dan dalam jalur jalan yang sama. Pada area ini untuk pengumpulan 
data dimana arus lalu lintas dinyatakan sebagai arus tidak terganggu.

Waktu masuk dan keluar (jam, dengan pendekatan detik) dari setiap kendaraan, dipisahkan dalam arah yang terekam untuk kendaraan yang melakukan Putaran balik, waktu masuk dan waktu dimana kendaraan mencapai fasilitas Putaran balik dicatat. Waktu keluar tidak dicatat untuk kendaraan yang melakukan Putaran balik.

\section{Alat Penelitian}

Alat-alat yang diperlukan antara lain adalah

a) Hand Counter untuk menghitung jumlah kendaraan;

b) Meteran untuk mengukur lebar jalan;

c) Alat tulis dan formulir penelitian untuk mencatat data.

\section{Tahapan Penelitian}

Tahapan penelitian dikelompokkan menjadi tiga tahap dengan uraian sebagai berikut :

\section{a) Tahap Persiapan}

Persiapan dalam studi meliputi kegiatan sebelum pengumpulan data dan pengolahan data. Adapun tahapan persiapan yaitu:

1) Menentukan kebutuhan data, yaitu dengan survey lokasi Putaran balik.

2) Mencari studi pustaka sebagai landasan teori.

b) Survei lokasi

langsung keadaan lapangan sesungguhnya. Hal ini mutlak dilakukan agar dapat diketahui kondisi aktual pada saat ini. Penelitian dilakukan pada hari saat jam sibuk sehari setelah hari libur dan di akhir pekan. Berdasarkan pola pergerakan yang dilihat dilapangan yaitu pada Pagi : Pukul 07.00 - 09.00 WIB dan Sore : Pukul 16.00 19.00 WIB.

\section{c) Pengumpulan Data}

Pengumpulan data yang di butuhkan pada penelitian ini adalah sebagai berikut :

\section{1) Data sekunder}

Pada data ini di lakukan survey terhadap kondisi dan situsai wilayah studi sebagai dasar penelitian. Beberapa data yang di rencanakan untuk dikumpulkan pada tahapan ini antara kain.

a). Peta jaringan Jalan Letnan Soepono (Arteri Permata Hijau)

b). Kajian transportasi

c). Kebijakan manajemen transportasi yang di gunakan

\section{2) Data primer}

Pengumpulan data primer dilakukan dengan meninjau dilapangan. survey yang di lakukan meliputi :

a). Survey jumlah kendaraan (Traffic Count)

b). Survey waktu tempuh

c). Survey pergerakan kendaraan putar balik arah

d). Survey hambatan samping di sekitar putaran balik

e). Survey tundaan

3) Variabel yang di ukur

Variabel utama yang akan diukur adalah waktu tempuh dari kendaraan melalui bagian jalan tertentu yang mempunyai fasilitas putaran balik. Waktu tempuh yang diukur ketika :

a). Tidak ada kendaraan yang melakukan Putaran balik

b). Satu kendaraan melakukan Putaran balik

Pengukuran dibatasi sebagai berikut :

(1) Tipe kendaraan (sesuai dengan system klasifikasi Bina Marga)

(a). Kendaraan ringan, indeks untuk kendaraan bermotor roda 4 
(empat), termasuk mobil penumpang, microbus, pick up dan mikrotruck.

(b). Kendaraan berat, indeks untuk kendaraan bermotor dengan roda lebih dari empat, termasuk bus, truk 2 as, truk 3 as, dan truk gandengan.

(2) Kondisi lalu lintas

(a). Arus lalu lintas tinggi, dalam pengertian arus lalu lintas padat atau mendekati kapasitas.

(b). Arus lalu lintas rendah berarti kondisi arus lalu lintas dengan $\mathrm{Q} / \mathrm{C}$ rasio lebih kecil dari 0,75 atau kecepatan rata-rata lebih dari 40 $\mathrm{km} / \mathrm{jam}$.

\section{d) Cek Kelengkapan Data}

Cek kelengkapan data diperlukan untuk dapat mengetahui jika masih ada kekurangan data yang dibutuhkan untuk analisis. Jika data masih ada kekurangan, maka harus dilakukan pengumpulan data kembali.

\section{e) Pengolahan Data}

Tujuan utama pengolahan data adalah membuat daftar kejadian lalu lintas yang berhubungan yang tidak secara langsung di ukur di lapangan. Pengolahan data dilakukan seperti :

1). Kondisi lalulintas.

2). Mencatat waktu masuk dan keluar daerah studi untuk setiap kendaraan.

3). Mencatat jumlah kendaraan melakukan putaran balik.

Memilih data yang digunakan sesuai dengan tujuan dari studi.

f) Analisis Pembahasan

Analisis pembahasan adalah upaya atau cara untuk mengolah data menjadi informasi sehingga karakteristik data tersebut bisa dipahami dan bermanfaat untuk solusi permasalahan, terutama masalah yang berkaitan dengan penelitian.

\section{g) Kesimpulan}

Kesimpulan adalah pernyataan singkat, jelas, dan sistematis dari keseluruhan hasil dari analisis, pembahasan, dan pengujian hipotesis dalam sebuah penelitian.

Gambaran yang lebih jelas dalam proses penelitian ini dapat dilihat pada Gambar 4.

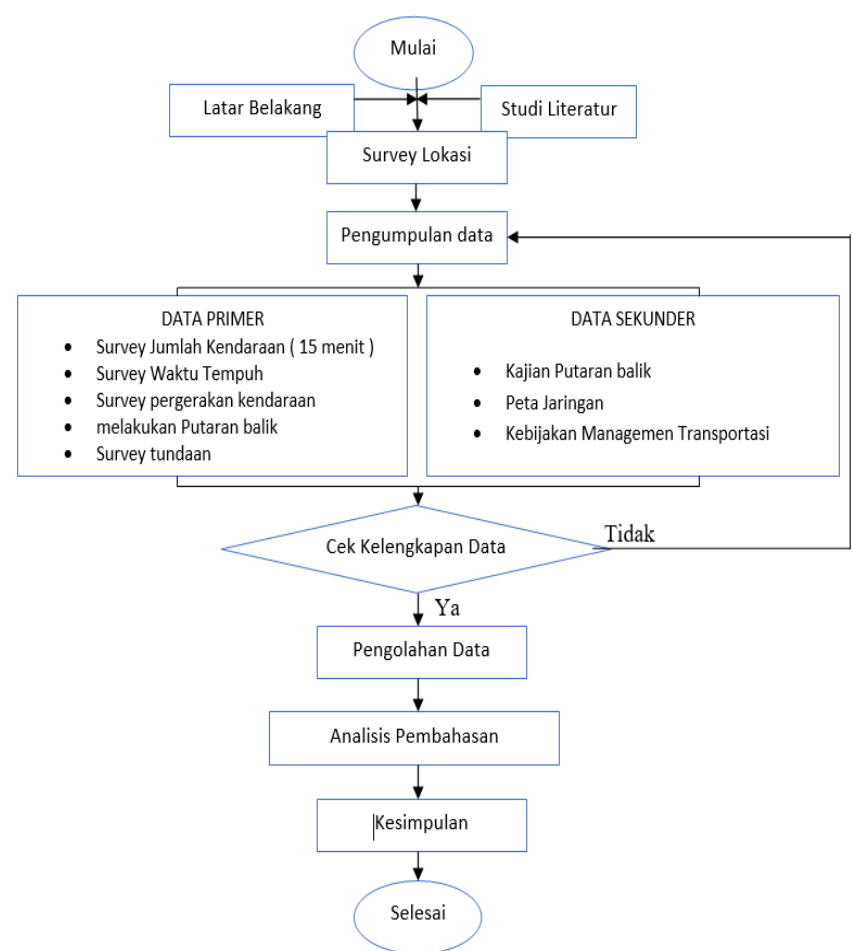

Gambar 4. Bagan Alir Penelitian

\section{Hasil Dan Pembahasan}

Lokasi ruas

: Jl. Letjen. Soepono

Tipe jalan

(Arteri Permata

Hijau) tepatnya

didepan ITC

Permata Hijau, Jakarta

Lebar jalan lajur khusus Busway :10,50 meter (arah

Kebon Jeruk - 
Simprug), 3,5

perlajur

: 10,50 meter (arah

Simprug - Kebon

Jeruk), 3,5 perlajur

Lebar median $\quad: 1,15$ meter

Gangguan samping : Rendah

Data jumlah penduduk: 1,89 juta orang

Dari data tersebut dapat dilakukan perhitungan kapasitas ruas pergerakan masing-masing arah, di mana kondisi kedua arah sama sehingga kapasitas per arah sama.

Tabel 12. Perhitungan Kapasitas Jalan

\begin{tabular}{|c|c|c|c|}
\hline No & Parameter & Kondisi & Nilai \\
\hline 1 & Kapasitas dasar & $6 / 2 \mathrm{D}$ & 4.950 \\
\hline 2 & $\begin{array}{l}\text { Factor koreksi lebar } \\
\text { jalan }\end{array}$ & $3,5 \mathrm{~m}$ & 1,00 \\
\hline 3 & $\begin{array}{l}\text { Factor koreksi } \\
\text { gangguan samping }\end{array}$ & Rendah & 0,97 \\
\hline 4 & $\begin{array}{l}\text { Factor koreksi } \\
\text { pembagian arah }\end{array}$ & $100 \%$ & 1,00 \\
\hline \multirow[t]{2}{*}{5} & $\begin{array}{l}\text { Factor koreksi } \\
\text { ukuran kota }\end{array}$ & $\begin{array}{l}1,89 \text { juta } \\
\text { penduduk }\end{array}$ & 1,00 \\
\hline & $\begin{array}{ll}\text { Kapasitas } & \text { actual } \\
(\mathrm{smp} / \mathrm{jam}) & \end{array}$ & Tiap arah & 4801 \\
\hline
\end{tabular}

Sumber : MKJI (1997)

\section{Analisa Jumlah Kendaraan U-Turn}

Data jumlah kendaraan U-Turn dibedakan menurut 2 jenis kendaraan, yaitu kendaraan ringan dan berat. Hasil pengamatan jumlah kendaraan U-Turn dapat dilihat ditabel 4.18

Tabel 13. data kendaraan yang melakukan $U$-Turn

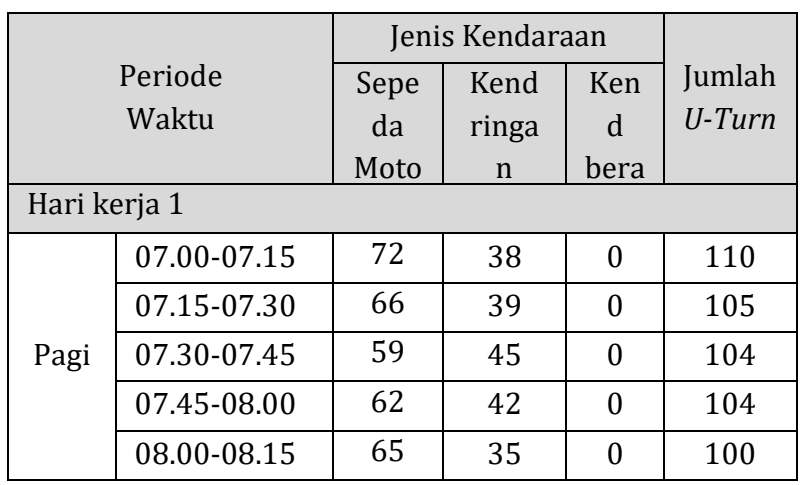

\begin{tabular}{|c|c|c|c|c|c|}
\hline & \multirow[b]{2}{*}{$\begin{array}{l}\text { Periode } \\
\text { Waktu }\end{array}$} & \multicolumn{3}{|c|}{ Jenis Kendaraan } & \multirow[b]{2}{*}{$\begin{array}{l}\text { Jumlah } \\
U \text {-Turn }\end{array}$} \\
\hline & & $\begin{array}{c}\text { Sepe } \\
\text { da } \\
\text { Moto }\end{array}$ & $\begin{array}{c}\text { Kend } \\
\text { ringa } \\
\mathrm{n}\end{array}$ & $\begin{array}{c}\text { Ken } \\
\mathrm{d} \\
\text { bera }\end{array}$ & \\
\hline \multicolumn{6}{|c|}{ Hari kerja 1} \\
\hline & $08.15-08.30$ & 59 & 37 & 0 & 96 \\
\hline & 08.30-08.45 & 63 & 41 & 0 & 104 \\
\hline & $08.45-09.00$ & 62 & 42 & 0 & 104 \\
\hline \multirow{12}{*}{ Sore } & $16.00-16.15$ & 57 & 71 & 0 & 128 \\
\hline & $16.15-16.30$ & 54 & 62 & 0 & 116 \\
\hline & $16.30-16.45$ & 49 & 80 & 0 & 129 \\
\hline & $16.45-17.00$ & 51 & 72 & 0 & 123 \\
\hline & $17.00-17.15$ & 49 & 68 & 0 & 117 \\
\hline & $17.15-17.30$ & 54 & 70 & 0 & 124 \\
\hline & $17.30-17.45$ & 50 & 71 & 0 & 121 \\
\hline & $17.45-18.00$ & 51 & 74 & 0 & 125 \\
\hline & $18.00-18.15$ & 54 & 71 & 0 & 125 \\
\hline & $18.15-18.30$ & 57 & 68 & 0 & 125 \\
\hline & $18.30-18.45$ & 49 & 67 & 0 & 116 \\
\hline & $18.45-19.00$ & 51 & 74 & 0 & 125 \\
\hline \multicolumn{2}{|r|}{ JUMLAH } & 113 & 1167 & $\mathbf{0}$ & 2301 \\
\hline
\end{tabular}

Sumber : Survey lapangan

Tabel 14. data kendaraan yang melakukan $U$-Turn

\begin{tabular}{|c|c|c|c|c|c|}
\hline & \multirow[b]{2}{*}{$\begin{array}{l}\text { Periode } \\
\text { Waktu }\end{array}$} & \multicolumn{3}{|c|}{ Jenis Kendaraan } & \multirow[b]{2}{*}{$\begin{array}{l}\text { Jumlah } \\
\text { U-Turn }\end{array}$} \\
\hline & & $\begin{array}{c}\text { Seped } \\
\text { a } \\
\text { Motor }\end{array}$ & $\begin{array}{c}\text { Kend } \\
\text { ringa } \\
\mathrm{n}\end{array}$ & $\begin{array}{c}\text { Ken } \\
\text { d } \\
\text { bera }\end{array}$ & \\
\hline \multicolumn{6}{|c|}{ Hari kerja 2} \\
\hline \multirow{8}{*}{ Pagi } & $07.00-07.15$ & 50 & 35 & 0 & 85 \\
\hline & $07.15-07.30$ & 66 & 41 & 0 & 107 \\
\hline & $07.30-07.45$ & 54 & 32 & 0 & 86 \\
\hline & $07.45-08.00$ & 61 & 35 & 0 & 96 \\
\hline & $08.00-08.15$ & 64 & 36 & 0 & 100 \\
\hline & $08.15-08.30$ & 67 & 31 & 0 & 98 \\
\hline & $08.30-08.45$ & 54 & 38 & 0 & 92 \\
\hline & $08.45-09.00$ & 61 & 36 & 0 & 97 \\
\hline \multirow{11}{*}{ Sore } & $16.00-16.15$ & 55 & 70 & 0 & 125 \\
\hline & $16.15-16.30$ & 53 & 65 & 0 & 118 \\
\hline & $16.30-16.45$ & 52 & 77 & 0 & 129 \\
\hline & $16.45-17.00$ & 50 & 73 & 0 & 123 \\
\hline & $17.00-17.15$ & 44 & 71 & 0 & 115 \\
\hline & $17.15-17.30$ & 43 & 70 & 0 & 113 \\
\hline & $17.30-17.45$ & 45 & 71 & 0 & 116 \\
\hline & $17.45-18.00$ & 50 & 69 & 0 & 119 \\
\hline & $18.00-18.15$ & 51 & 71 & 0 & 122 \\
\hline & $18.15-18.30$ & 57 & 79 & 0 & 136 \\
\hline & $18.30-18.45$ & 54 & 72 & 0 & 126 \\
\hline
\end{tabular}




\begin{tabular}{|c|c|c|c|c|}
\hline \multirow[b]{2}{*}{$\begin{array}{l}\text { Periode } \\
\text { Waktu }\end{array}$} & \multicolumn{3}{|c|}{ Jenis Kendaraan } & \multirow[b]{2}{*}{$\begin{array}{l}\text { Jumlah } \\
\text { U-Turn }\end{array}$} \\
\hline & $\begin{array}{c}\text { Seped } \\
\text { a } \\
\text { Motor }\end{array}$ & $\begin{array}{l}\text { Kend } \\
\text { ringa } \\
n\end{array}$ & $\begin{array}{c}\text { Ken } \\
\text { d } \\
\text { bera }\end{array}$ & \\
\hline $18.45-19.00$ & 50 & 69 & 0 & 119 \\
\hline JUMLAH & 1081 & 1141 & $\mathbf{0}$ & 2222 \\
\hline
\end{tabular}

Sumber : Survey lapangan

Tabel 15. data kendaraan yang melakukan $U$-Turn

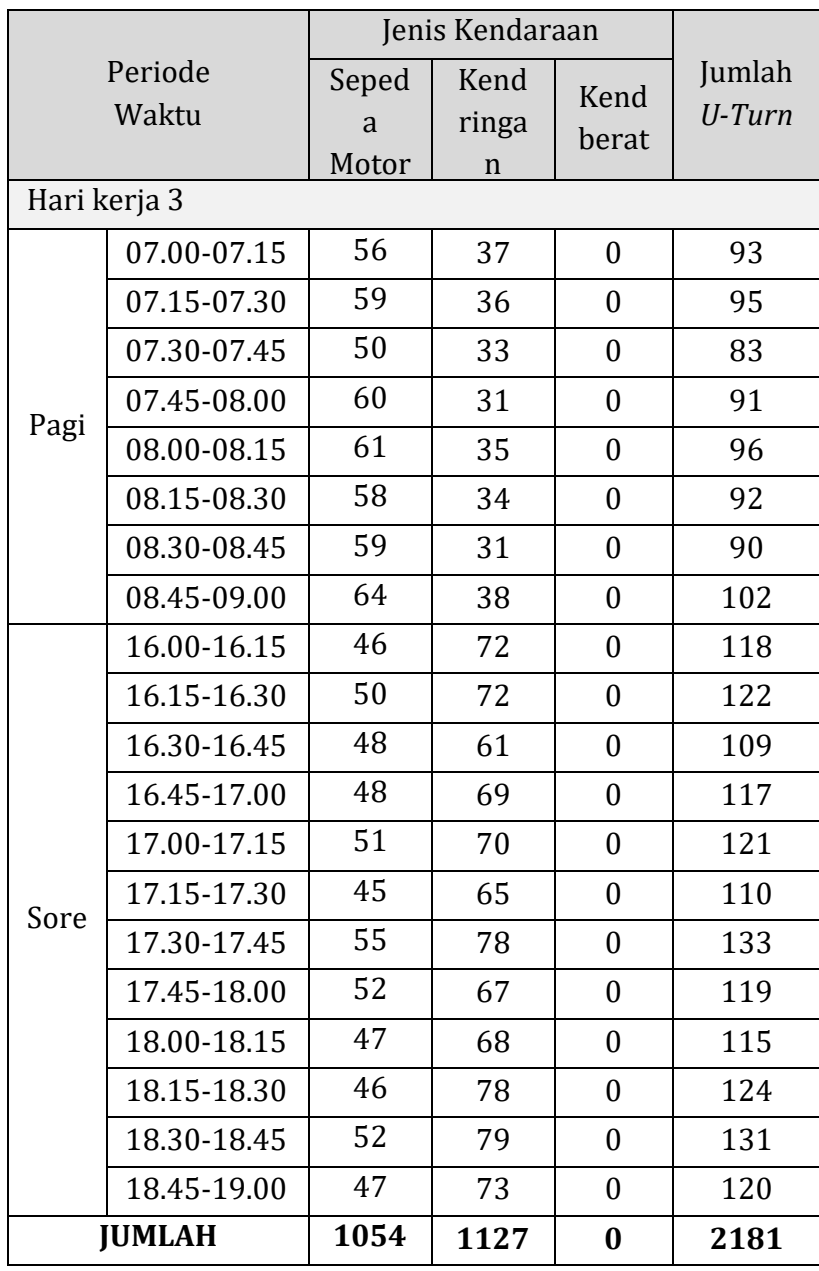

Sumber : Survey lapangan

Dari data tersebut, diketahui jumlah kendaraan ringan yang melakukan U-Turn pada Hari kerja 1 sebanyak 2301 kendaraan, hari kerja 2 sebanyak 2222 kendaraan, hari kerja 3 sebanyak 2181 kendaraan dan kendaraan berat yang melakukan U-Turn pada hari kerja 1 sebanyak 0 kendaraan, Hari kerja 2 sebanyak 0 kendaraan, Hari kerja 3 sebanyak 0 kendaraan.

\section{Analisa Tundaan Operasional}

Tundaan operasional adalah besarnya tundaan (detik) yang disebabkan oleh sebuah kendaraan yang melakukan gerakan U-Turn tunggal, yang dialami oleh tiap kendaraan yang melaju searah maupun berlawanan arah dengan kendaraan $U$-Turn tersebut.

Tundaan operasional dibedakan dalam dua tipe arus lalu lintas :

a. Pada arah yang sama

b. Untuk arah berlawanan

Hasil pengamatan tundaan operasional yang disebabkan oleh gerakan $U$-Turn dalam arah yang sama Simprug - Kebon Jeruk di sajikan pada tabel 16.

Data diperoleh berdasarkan urutan kendaraan yang melakukan U-Turn tunggal masing-masing arah, baik arah Kebon Jeruk maupun Simprug. Dari urutan kendaraan yang melakukan $U$-Turn, kemudian dihitung banyaknya kendaraan yang melakukan $U$ Turn dalam satu kasus dan besarnya tundaan operasional (detik). Sehingga dapat diperoleh tundaan operasional rata-rata per kendaraan (detik) dengan membagi besarnya tundaan operasional dengan total kendaraan yang melakukan manuver $U$ Turn.

Tabel 16. Tundaan Operasional Disebabkan oleh Gerakan $U$-Turn Dalam Arah yang sama Simprug - Kebon Jeruk

\begin{tabular}{|c|c|c|c|c|}
\hline \multirow{2}{*}{\multicolumn{2}{|c|}{$\begin{array}{c}\text { No kasus } U \text { - } \\
\text { Turn }\end{array}$}} & $\begin{array}{c}\text { Total } \\
\text { kendaraan }\end{array}$ & \multirow{2}{*}{$\begin{array}{c}\text { Tundaa } \\
n \\
\text { operasi } \\
\text { onal } \\
\text { (detik) }\end{array}$} & $\begin{array}{c}\text { Tundaan } \\
\text { operasional }\end{array}$ \\
\hline & & Kendaraan & & $\begin{array}{l}\text { rata-rata } \\
\text { per }\end{array}$ \\
\hline \multicolumn{5}{|c|}{ Hari kerja 1} \\
\hline \multirow[t]{2}{*}{ Pagi } & \multicolumn{4}{|c|}{ Pukul 07.00-09.00 } \\
\hline & & 164 & 1575 & 9.6 \\
\hline \multirow[t]{2}{*}{ Sore } & \multicolumn{4}{|c|}{ Pukul 16.00-19.00 } \\
\hline & & 568 & 4430 & 7.8 \\
\hline & & & & \\
\hline
\end{tabular}




\begin{tabular}{|l|c|r|r|r|}
\hline & $\begin{array}{c}\text { Juml } \\
\text { ah }\end{array}$ & 1367 & 9958 & 3377.26 \\
\hline & & & & \\
\hline & $\begin{array}{c}\text { rata- } \\
\text { rata }\end{array}$ & 3.13 & 22.79 & 7.73 \\
\hline & & & & \\
\hline
\end{tabular}

\section{Analisa Volume Lalu lintas}

Dari data volume lalu lintas kedua arah diketahui bahwa volume lalu lintas untuk arah Kebon Jeruk - Simprug berkisar antara 2678,44 smp/jam sampai 4908,65 smp/jam dan untuk arah Simprug - Kebon Jeruk antara 1813,2 smp/jam sampai 2782,15 smp/jam.

Volume jam puncak untuk arah Kebon Jeruk - Simprug terjadi pada hari Kerja 1 pukul 07.00-09.00, sedangkan untuk arah Simprug - Kebon Jeruk pada hari Kerja 1 pukul 16.00 -19.00 .

\section{Tingkat Pelayanan Jalan}

Untuk meningkatkan tingkat pelayanan jalan diperlukan data volume lalu lintas dan kapasitas jalan. Dari perhitungan diperoleh nilai Q/C pada arah Kebon Jeruk - Simprug di tabel 17 dan arah Simprug - Kebon Jeruk 18.

Tabel 17. Nilai Q/C arah Kebon JerukSimprug

\begin{tabular}{|c|c|c|c|c|}
\hline \multicolumn{2}{|c|}{$\begin{array}{l}\text { Periode } \\
\text { waktu }\end{array}$} & $\begin{array}{c}\text { Volume } \\
\text { (Q) } \\
\text { Smp/Jam }\end{array}$ & $\begin{array}{c}\text { Kapasitas } \\
\text { ( C ) } \\
\text { Smp/Jam }\end{array}$ & Q/C \\
\hline \multicolumn{5}{|c|}{ Hari kerja 1} \\
\hline Pagi & $\begin{array}{l}07.00- \\
09.00\end{array}$ & 4908.65 & 4801 & 1.02 \\
\hline Sore & $\begin{array}{l}16.00- \\
19.00\end{array}$ & 2945.95 & 4801 & 0.61 \\
\hline \multicolumn{5}{|c|}{ Hari kerja 2} \\
\hline Pagi & $\begin{array}{l}07.00- \\
09.00\end{array}$ & 4713.68 & 4801 & 0.98 \\
\hline Sore & $\begin{array}{l}16.00- \\
19.00\end{array}$ & 2965.88 & 4801 & 0.62 \\
\hline Hari & & & & \\
\hline
\end{tabular}

\begin{tabular}{|l|l|l|l|l|}
\hline \multicolumn{2}{|c|}{$\begin{array}{c}\text { Periode } \\
\text { waktu }\end{array}$} & $\begin{array}{c}\text { Volume } \\
\text { ( Q ) } \\
\text { Smp/Jam }\end{array}$ & $\begin{array}{c}\text { Kapasitas } \\
\text { (C) } \\
\text { Smp/Jam }\end{array}$ & Q/C \\
\hline Pagi & $\begin{array}{l}07.00- \\
09.00\end{array}$ & 4686.2 & 4801 & 0.98 \\
\hline & & & & 0.61 \\
\hline Sore & $\begin{array}{l}16.00- \\
19.00\end{array}$ & 2920.05 & 4801 & 0.60 \\
\hline
\end{tabular}

Sumber : Survey lapangan

Tabel 18. Nilai Q/C arah Simprug Kebon Jeruk

\begin{tabular}{|c|c|c|c|c|}
\hline \multicolumn{2}{|c|}{$\begin{array}{l}\text { Periode } \\
\text { waktu }\end{array}$} & $\begin{array}{c}\text { Volume ( } \\
\text { Q) } \\
\text { Smp/Jam }\end{array}$ & $\begin{array}{c}\text { Kapasitas } \\
\text { (C) } \\
\text { Smp/Jam }\end{array}$ & $\mathbf{Q} / \mathbf{C}$ \\
\hline \multicolumn{5}{|c|}{ Hari kerja 1} \\
\hline Pagi & $\begin{array}{l}07.00- \\
09.00\end{array}$ & 2100 & 4801 & 0.44 \\
\hline Sore & $\begin{array}{l}16.00- \\
19.00\end{array}$ & 2782.15 & 4801 & 0.58 \\
\hline \multicolumn{5}{|c|}{ Hari kerja 2} \\
\hline Pagi & $\begin{array}{l}07.00- \\
09.00\end{array}$ & 1995.05 & 4801 & 0.42 \\
\hline Sore & $\begin{array}{l}16.00- \\
19.00\end{array}$ & 2672.7 & 4801 & 0.56 \\
\hline \multicolumn{5}{|c|}{ Hari kerja 3} \\
\hline Pagi & $\begin{array}{l}07.00- \\
09.00\end{array}$ & 1813.2 & 4801 & 0.38 \\
\hline Sore & $\begin{array}{l}16.00- \\
19.00\end{array}$ & 2746.545 & 4801 & 0.57 \\
\hline
\end{tabular}

Sumber : Survey lapangan

Nilai Q/C untuk arah Kebon Jeruk - Simprug berfluktuasi antara 0,56 sampai 1,02, sedangkan untuk arah Simprug - Kebon Jeruk antara 0,38 sampai 0,58 Untuk arah Kebon Jeruk - Simprug nilai Q/C maksimum terjadi pada hari Kerja 1 pukul 07.00-09.00 dimana Q/C lebih dari 0,75, sedangkan untuk arah Simprug - Kebon Jeruk terjadi pada hari kerja 1 pukul 16.00-19.00 lebih dari 0,58.

Kondisi lalu lintas dengan volume melebihi kapasitas terjadi pada arah Kebon Jeruk Simprug hari kerja 1 dan hari kerja 2 antara 
pukul 07.00 sampai 09.00 dimana Q/C lebih dari 0,75. Sedangkan kondisi lalu lintas mendekati kapasitas arah Simprug - Kebon Jeruk pada hari kerja 1 antara pukul 16.00 sampai 19.00 dimana nilai $\mathbf{Q} / \mathbf{C}$ kurang dari 0,75 . Hal tersebut menyebabkan kondisi lalu lintas terganggu dan tingkat kenyamanan pengguna jalan menjadi berkurang.

\section{Analisa Kecepatan}

Kecepatan diperoleh dari data waktu tempuh pada dua kondisi, yakni kondisi arus terganggu dan tidak terganggu. Dari dua kondisi tersebut, Kemudian diperoleh selisih kecepatan antara waktu arus terganggu dan tidak terganggu.

Untuk menghitung nilai kecepatan dapat diperoleh dengan rumus:

Kecepatan perjalanan $=\mathbf{3 , 6}(\mathbf{d} / \mathbf{x})$

Keterangan :

d : panjang dari daerah yang diamati (100 $\mathrm{m}$ )

$\mathrm{x}$ : rata-rata waktu tempuh ( detik) untuk melewati daerah yang diamati

Hasil perhitungan kecepatan kondisi arus terganggu dan tidak terganggu serta selisih kecepatannya untuk arah Kebon Jeruk Simprug dapat dilihat di tabel dan untuk arah Simprug - Kebon Jeruk dapat dilihat di tabel.

Dari tabel 19 selisih kecepatan kedua kondisi arah Kebon Jeruk - Simprug antara 17,26 sampai 32,95 km/jam Selisih kecepatan terbesar terjadi pada hari Kerja 1 pukul 16.00-19.00, sedangkan dari tabel 4.26 selisih kecepatan kedua kondisi arah Simprug - Kebon Jeruk antara 19,55 sampai $27,75 \mathrm{~km} /$ jam Selisih kecepatan terbesar terjadi pada hari Kerja 2 pukul 16.00 -19.00 Analisa dari hasil perhitungan tersebut adalah bahwa keberadaan kendaraan yang melakukan U-Turn sangat mempengaruhi kecepatan kendaraan yang lain baik dalam arah yang sama maupun arah berlawanan.
Kendaraan yang melewati daerah pengamatan pada kondisi ada U-Turn cenderung mengurangi kecepatannya, sehingga kecepatan kendaraan pada kondisi ada $U$-Turn lebih rendah dari pada kondisi tidak ada $U$-Turn.

Tabel 19. Selisih kecepatan antara kondisi arus terganggu dengan tidak terganggu Arah Kebon Jeruk - Simprug

\begin{tabular}{|c|c|c|c|c|c|c|}
\hline \multirow{2}{*}{\multicolumn{2}{|c|}{$\begin{array}{c}\text { Periode } \\
\text { waktu }\end{array}$}} & \multicolumn{2}{|c|}{$\begin{array}{c}\text { Kondisi arus } \\
\text { tidak terganggu }\end{array}$} & \multicolumn{2}{|c|}{$\begin{array}{l}\text { Kondisi arus } \\
\text { terganggu }\end{array}$} & \multirow{2}{*}{$\begin{array}{c}\text { Selisih } \\
\text { kecepat } \\
\text { an } \\
(\mathrm{km} / \mathrm{ja} \\
\mathrm{m})\end{array}$} \\
\hline & & $\begin{array}{l}\operatorname{tr} \\
\text { (detik }\end{array}$ & $\begin{array}{c}\mathrm{Vr} \\
(\mathrm{km} / \mathrm{ja} \\
\mathrm{m})\end{array}$ & $\begin{array}{l}\text { Tr } \\
\text { (detik }\end{array}$ & $\begin{array}{l}\mathrm{Vr} \\
(\mathrm{km} \\
/ \mathrm{ja} \\
\mathrm{m})\end{array}$ & \\
\hline \multicolumn{7}{|c|}{ Hari kerja 1} \\
\hline Pagi & $\begin{array}{l}07.0 \\
0- \\
09.0 \\
0\end{array}$ & 5.39 & 66.94 & 9.12 & $\begin{array}{l}39.4 \\
9\end{array}$ & 27.45 \\
\hline Sore & $\begin{array}{l}16.0 \\
0- \\
19.0 \\
0\end{array}$ & 5.11 & 70.50 & 9.21 & $\begin{array}{l}39.1 \\
3\end{array}$ & 31.37 \\
\hline \multicolumn{7}{|c|}{ Hari kerja 2} \\
\hline Pagi & $\begin{array}{l}07.0 \\
0- \\
09.0 \\
0\end{array}$ & 5.36 & 67.52 & 9.24 & $\begin{array}{l}39.0 \\
1\end{array}$ & 28.51 \\
\hline Sore & $\begin{array}{l}16.0 \\
0- \\
19.0 \\
0\end{array}$ & 5.07 & 71.1 & 8.46 & $\begin{array}{l}42.6 \\
2\end{array}$ & 28.48 \\
\hline \multicolumn{7}{|c|}{ Hari kerja 3} \\
\hline Pagi & $\begin{array}{l}07.0 \\
0- \\
09.0 \\
0\end{array}$ & 5.81 & 62.01 & 8.82 & $\begin{array}{l}40.8 \\
7\end{array}$ & 21.14 \\
\hline Sore & $\begin{array}{l}16.0 \\
0- \\
19.0 \\
0\end{array}$ & 5.32 & 67.92 & 8.14 & $\begin{array}{l}44.2 \\
8\end{array}$ & 23.64 \\
\hline
\end{tabular}

Sumber : Survey lapangan 
Tabel 20. Selisih kecepatan antara kondisi arus terganggu dengan tidak terganggu Arah Simprug - Kebon Jeruk

\begin{tabular}{|c|c|c|c|c|c|c|}
\hline \multirow{2}{*}{\multicolumn{2}{|c|}{$\begin{array}{c}\text { Periode } \\
\text { waktu }\end{array}$}} & \multicolumn{2}{|c|}{$\begin{array}{c}\text { Kondisi arus } \\
\text { tidak } \\
\text { terganggu }\end{array}$} & \multicolumn{2}{|c|}{$\begin{array}{c}\text { Kondisi arus } \\
\text { terganggu }\end{array}$} & \multirow{2}{*}{$\begin{array}{c}\text { Selisih } \\
\text { kecep } \\
\text { atan } \\
(\mathrm{km} / \mathrm{j} \\
\text { am) }\end{array}$} \\
\hline & & $\begin{array}{l}\operatorname{tr}( \\
\text { deti } \\
\mathrm{k})\end{array}$ & $\begin{array}{c}\mathrm{Vr} \\
(\mathrm{km} / \mathrm{j} \\
\mathrm{am})\end{array}$ & $\begin{array}{l}\text { Tr } \\
\text { (det } \\
\text { ik) }\end{array}$ & $\begin{array}{c}\mathrm{Vr} \\
(\mathrm{km} / \mathrm{j} \\
\mathrm{am})\end{array}$ & \\
\hline \multicolumn{7}{|c|}{ Hari kerja 1} \\
\hline $\begin{array}{l}\mathrm{Pa} \\
\text { gi }\end{array}$ & $\begin{array}{l}07.0 \\
0- \\
09.0 \\
0\end{array}$ & $\begin{array}{l}4.9 \\
3\end{array}$ & 73.34 & 9.12 & 39.50 & 33.84 \\
\hline $\begin{array}{l}\text { So } \\
\text { re }\end{array}$ & $\begin{array}{l}16.0 \\
0- \\
19.0 \\
0\end{array}$ & $\begin{array}{l}5.4 \\
7\end{array}$ & 65.87 & 9.16 & 39.31 & 26.56 \\
\hline \multicolumn{7}{|c|}{ Hari kerja 2} \\
\hline $\begin{array}{l}\mathrm{Pa} \\
\text { gi }\end{array}$ & $\begin{array}{l}07.0 \\
0- \\
09.0 \\
0\end{array}$ & $\begin{array}{l}5.4 \\
0\end{array}$ & 66.83 & 8.43 & 42.75 & 24.08 \\
\hline $\begin{array}{l}\text { So } \\
\text { re }\end{array}$ & $\begin{array}{l}16.0 \\
0- \\
19.0 \\
0 \\
\end{array}$ & $\begin{array}{l}5.1 \\
1\end{array}$ & 70.55 & 9.01 & 39.95 & 30.6 \\
\hline \multicolumn{7}{|c|}{ Hari kerja 3} \\
\hline $\begin{array}{l}\mathrm{Pa} \\
\text { gi }\end{array}$ & $\begin{array}{l}07.0 \\
0- \\
09.0 \\
0\end{array}$ & $\begin{array}{l}5.4 \\
1\end{array}$ & 66.75 & 8.19 & 43.98 & 22.77 \\
\hline $\begin{array}{l}\text { So } \\
\text { re }\end{array}$ & $\begin{array}{l}16.0 \\
0- \\
19.0 \\
0\end{array}$ & $\begin{array}{l}5.1 \\
8\end{array}$ & 69.63 & 8.99 & 40.10 & 29.53 \\
\hline
\end{tabular}

Sumber : Survey lapangan

\section{Analisa $U$-Turn}

Dari hasil pengamatan di lapangan diperoleh data kendaraan ringan yang melakukan $U$ Turn pada hari Kerja 1 sebanyak 1367 kendaraan, kendaraan berat sebanyak 0 kendaraan, hari Kerja 2 sebanyak 1309 kendaraan ringan, kendaraan berat sebanyak 0 kendaraan, hari Jum'at sebanyak
1295 kendaraan ringan, kendaraan berat sebanyak 0 kendaraan.

Jumlah kendaraan U-Turn terbesar dengan interval 1 jam terjadi pada hari Kerja 1 pukul 16.00-19.00 sebanyak 327 kasus. Dan dalam interval waktu pengamatan 15 menit kejadian $U$-Turn berfluktuasi antara 38 sampai 94 kasus. Rata-rata kejadian U-Turn pada interval waktu 15 menit terdapat 66 kendaraan yang melakukan U-Turn. Banyaknya kendaraan yang melakukan $U$ Turn tersebut menyebabkan kecepatan kendaraan yang melewati daerah pengamatan menurun.( tabel 19 dan 20)

\section{Simpulan}

Proses pengamatan, perhitungan dan analisis pada arus lalu lintas yang terjadi karena pengaruh manuver berbalik arah kendaraan pada jalan raya Letjen Soepono dapat disimpulkan sebagai berikut :

1. Volume terbesar diruas jalan Letjen Soepono (Arteri Permata Hijau) yang terjadi pada hari kerja sekitar pukul 07.00 - 08.00 WIB dari arah Kebo Jerok - Simprug adalah $4908.65 \mathrm{smp} / \mathrm{jam}$.

2. Arus lalu lintas pada arah Kebon Jeruk Simprug 4908,68 smp/jam dengan Q/C rasio tertinggi 1.02, Simprug - Kebon Jeruk arus 1813.2 sampai $2782.15 \mathrm{smp}$ per jam dengan $\mathbf{Q} / \mathbf{C}$ rasio tertinggi 0,58 .

3. Tundaaan operasional yang diakibatkan oleh pergerakan putaran balik dengan rata-rata 1764.2 detik. Dengan tundaan operasional terbesar 6.77 - 7.73 detik per kendaraan, Tundaan operasional terbesar dari hasil perhitungan lebih dari 1 jam.

4. Dapat disimpulkan bahwa :

a. Kondisi 1, Kepadatan $\mathrm{D}_{1}=72.82$ $\mathrm{smp} / \mathrm{km}$ yang bergerak dengan kecepatan $S_{1}=67.40 \mathrm{~km} /$ jam. 
b. Kondisi 2, Kepadatan $\mathrm{D}_{2}=102.86$ $\mathrm{smp} / \mathrm{km}$ yang bergerak dengan kecepatan $\mathrm{S}_{1}=47.42 \mathrm{~km} / \mathrm{jam}$.

c. Ruas JL.Pahlawan Seribu, Area ITC Permata Hijau mempunyai derajat kejenuhan yang cukup tinggi $(\mathrm{Q} / \mathrm{C}>0.97)$ dengan tingkat pelayanan jalan / level of service $\mathrm{E}$.

d. Persimpangan bersinyal yang berada tidak jauh dari lokasi penelitian menyebabkan pengaruh yang cukup besar pada tundaan kendaraan. Antrian kendaraan terjadi sampai dengan lokasi UTurn sehingga mempengaruhi perilaku kendaraan yang akan melakukan manuver U-Turn.

\section{Daftar Pustaka}

Direktorat Jenderal Bina Marga, 1997, Manual Kapasitas Jalan Indonesia (MKJI), Bina Marga, Jakarta.

Direktorat Jenderal Bina Marga, Pedoman Perencanaan Putaran Balik (U-Turn), Departemen Pekerjaan Umum, Jakarta.

Direktorat Pembinaan Jalan Kota, 1990, Tata Cara Perencanaan Pemisah, Bina Marga, Jakarta.

Departemen Perhubungan,2005 : Peraturan Dirjen Perhubungan Darat No. 770.

Khisty,C. Jotin, B. Kent Lall, 2003, Dasardasar Rekayasa Transportasi Jilid I, Penerbit Erlangga, Jakarta.

Mochamad Ichsan Nugraha. 2016, Analisis Kinerja Pelayanan Putaran Balik Arah (U-TURN), Terhadap Pengadaan Shelter Trans Jogja.

Munawar, Ahmad, 1995, Dasar-Dasar Teknik Transportasi, Beta Offset, Yogyakarta.

Ofyar Z. Tarmin, 2003, Perencanaan \& Pemodelan Transportasi Edisi Kesatu, Penerbit ITB, Bandung.
Standar Nasional Indonesia, 2008, Spesifikasi Bukaan Pemisah Jalur, Bina Marga, Jakarta.

Widyaningsih, Nunung, 2005, Modul Mata Kuliah Rekayasa Transportasi, Universitas Mercubuana, Jakarta. 
